\title{
Evidence for post-Acadian through Alleghanian deformation in eastern Maine: multiple brittle reactivation of the Norumbega Fault system
}

\author{
Chunzeng Wang ${ }^{1}$ and Allan Ludman ${ }^{2}$ \\ 1. Department of Geology and Geography, Hunter College (CUNY), 695 Park Avenue, New York, NY 10021, U.S.A. \\ <cwang@geo.hunter.cuny.edu> \\ 2. School of Earth and Environmental Sciences, Queens College (CUNY), Flushing, NY 11367, U.S.A. \\ Date received:August 20,2002 I Date accepted:December 23, 2002
}

\begin{abstract}
Detailed mapping in eastern and east-central Maine reveals a complex history of multiple brittle reactivations along the Norumbega fault system (NFS) following initial late Acadian (380 Ma) ductile shearing. Three distinct episodes of brittle faulting are now recognized, each characterized by a unique combination of fault kinematics and dynamics. These three events record a previously poorly-known part of northern Appalachian history - the transition from Acadian stress regimes related to one set of plate collisions to Alleghanian stresses associated with very different plate interactions.

Although NFS ductile strain was partitioned into three major high-strain zones in eastern Maine, only the central Waite zone experienced significant post-Acadian brittle deformation. The Waite zone is therefore considered the master fault for the brittle reactivations. All postAcadian redbed exposures are located in the Waite zone, including two new fault-bounded slivers discovered during this study.

The first two brittle faulting episodes predated deposition of the post-Acadian redbeds and both involved dextral strike-slip motion although episode 1 also had a significant dip-slip component. Episode 2 was responsible for the formation of the post-Acadian (Carboniferous?) redbed basins, possibly through a pull-apart mechanism. Brittle episodes 1 and 2 probably occurred in late Devonian through Mississippian times. Oblique (reverse-sinistral) faulting during episode 3 deformed the redbeds and is attributed to the Permian Alleghanian orogeny. Paleostress analyses based on abundant outcrop-scale conjugate faults suggest that the maximum principal stress $\left(\sigma_{1}\right)$ for the three brittle episodes rotated counterclockwise from a WNW-ESE orientation during episode 1 to NE-SW for episode 2 and changed to N-S for episode 3.
\end{abstract}

\section{RESUMÉ}

La cartographie détaillée de l'Est et du centre-est du Maine révèle un passé complexe de rétablissements fragiles multiples le long du système de failles de Norumbega (SFN) à la suite du cisaillement ductile initial de l'Acadien tardif $(380 \mathrm{Ma})$. On reconnaît maintenant trois épisodes distincts de formation de failles fragiles, caractérisés chacun par une combinaison unique de la cinématique et de la dynamique des failles. Ces trois épisodes ont enregistré une tranche auparavant mal connue du passé du nord des Appalaches : la transition des régimes de contrainte acadiens apparentés à une série de collisions de plaques, aux contraintes alléghaniennes associées à des interactions entre plaques très différentes.

Même si la déformation ductile du SFN a été segmentée en trois zones principales à forte contrainte dans l'Est du Maine, seule la zone centrale de Waite a subi une déformation fragile prononcée après l'Acadien. La zone de Waite est par conséquent considérée comme la faille maîtresse des rétablissements fragiles. Tous les affleurements de couches rouges ultérieurs à l'Acadien se situent dans la zone de Waite, notamment deux nouvelles tranches délimitées par des failles découvertes au cours de la présente étude.

Les deux premiers épisodes de formation de failles cassantes ont précédé la sédimentation des couches rouges ultérieures à l'Acadien et ont tous deux comporté un coulissage dextre, bien que le premier épisode ait en plus présenté un rejet incliné marqué. Le second épisode a entrainé la formation des bassins de couches rouges ultérieurs à l'Acadien (Carbonifère?), possiblement en vertu d'un phénomène d'extension. Les deux premiers épisodes fragiles sont probablement survenus au cours du Dévonien tardif à l'époque du Mississippien. La formation de failles diagonales (inverses-senestres) au cours du troisième épisode a déformé les couches rouges; on l'attribue à l'orogenèse alléghanienne du Permien. Des analyses des paléocontraintes basées sur les failles conjuguées d'affleurement abondantes permettent de supposer que la contrainte principale maximale $\left(\sigma_{1}\right)$ des trois épisodes fragiles a pivoté dans le sens antihoraire, passant d'une orientation ONO-ESE au cours du premier épisode, au NE-SO au cours du deuxième épisode, puis au N-S au cours du troisième épisode.

\section{INTRODUCTION}

Deformation in New England during the transition from the Acadian (late Silurian to middle Devonian) to the Alleghanian (Permian) orogenies is poorly understood because there are few definitively post-Acadian rocks and structures in which such mid-late Paleozoic structures might be readily distinguished from Acadian features. As a matter of fact, little attention has been paid to post-Acadian deformation, especially in northern New England because it scarcely affects older structures and the regional map pattern. Our detailed mapping along the Norumbega fault system (NFS) in eastern Maine in recent years, however, revealed a 
variety of rocks and structures now attributable to this time span, including post-Acadian plutons, mylonite and other fault rocks of the Norumbega system, and unmetamorphosed redbeds and related strata in several small post-Acadian molasse basins. These features record a complex history of multiple brittle faulting events from which stress fields associated with post-Acadian and Alleghenian deformation may be deduced. These data provide a key to understanding the major tectonic directions of maximum principal stresses during the transition.

Although brittle reactivation of early Norumbega ductile shear zones has been documented in both metasedimentary (Ludman 1998) and granitic (Ludman and Gibbons 1999) rocks, this is the first attempt to detail the history and nature of fault reactivation and to investigate the dynamics and stress fields accompanying those episodes. The purposes of this paper, therefore, are to (1) describe the nature, sequence, and timing of post-Acadian brittle deformation in eastern and east-central Maine, (2) deduce paleostress fields for each recognized post-Acadian deformational event, and (3) investigate the origin of small molasse basins distributed along the NFS.

\section{GEOLOGIC SETTING}

Eastern and east-central Maine are underlain by several northeast-trending lithotectonic belts composed largely of Cambrian through early Devonian metasedimentary and/or metavolcanic rocks and intruded by bimodal Silurian through Devonian plutons (Fig. 1; Osberg et al. 1985). Pre-Silurian rocks of the Miramichi and St. Croix belts were folded in the Middle Ordovician, and the entire region was subsequently affected by Acadian deformation. The earliest, Late Silurian, Acadian deformation is recorded in the Fredericton belt in eastern Maine (West et al. 1992), and a later Middle Devonian phase is indicated by an unconformity separating Early Devonian volcanic rocks in the Coastal Volcanic belt from the overlying Late Devonian Perry Formation. The precise age of Acadian deformation in the Miramichi terrane is unknown, but it must have preceded emplacement of the Pokiok and Bottle Lake granitic batholiths at approximately $380 \mathrm{Ma}$ because of the intrusive contact relationship between these batholiths and Acadian structures and features. Very low regional metamorphic grade (chlorite and sub-chlorite), low-pressure contact metamorphism (cordierite-andalusite), and miarolitic cavities in granite batholiths indicate that the study area remained at shallow crustal levels throughout this polydeformational history.

Extensive plutonism accompanied both phases of the Acadian orogeny. Late Silurian bimodal plutonic rocks (gabbro followed by granite) have now been recognized throughout eastern and coastal Maine (Abbott 1978; Jurinski 1987; Hill and Abbott 1989; Hogan and Sinha 1989; West et al. 1992), and an even greater volume of bimodal magmatism followed the Early Devonian phase. The latter episode was responsible for the largest granite batholiths in eastern Maine (Deblois, $384 \pm 5 \mathrm{Ma}$, Ludman et al. 1999; Bottle Lake, $380 \pm 5$, Ayuso et al. 1984; Lucerne, $380 \pm 4$, Wones and Ayuso 1993) and the Pokiok pluton $(380 \pm 5 \mathrm{Ma})$ that spans the Maine-New Brunswick border.
The Norumbega fault system (NFS), originally named as "Norumbega fault" north of Penobscot Bay (Stewart and Wones 1974; Wones 1978), has been recognized recently as one of the largest transcurrent fault systems in the northern Appalachian orogen (Hubbard et al. 1995; Ludman et al. 1999). In eastern Maine, the NFS is located largely within turbidites of the Fredericton belt, although its northernmost branch currently separates the Miramichi and Fredericton belts and its effects are obvious in the Deblois, Lucerne, and Bottle Lake granites. The NFS is about $30 \mathrm{~km}$ wide at the Maine-New Brunswick border, but strain was distributed inhomogeneously across the system. Norumbega faulting began in eastern Maine at approximately 380 $\mathrm{Ma}$, following rapid cooling of the Deblois pluton to temperatures of the ductile-brittle transition for its epizonal host rocks (Ludman et al. 2000). Previous studies showed that the initial NFS faulting was largely ductile and accompanied dextral transcurrent motion (Swanson 1992, 1995; West and Lux 1993; Hubbard et al. 1995; Ludman 1998; Wang and Ludman 1999; Short 2000). The initial ductile shear strain was concentrated in the Codyville, Waite, and Kellyland ductile shear zones in eastern Maine, each 2-5 km wide and separated from one another by regions of far lower strain (Ludman 1991; Fig. 1). These three ductile shear zones together comprise the Norumbega fault system in eastern Maine and became loci of subsequent brittle reactivation discussed in this paper.

Detailed mapping in the Fredericton belt (Ludman 1998) and the Deblois pluton (Ludman and Gibbons 1999; Wang and Ludman 1999; Wang et al. 2000) revealed multiple episodes of brittle reactivation along the NFS. Thermochronology in both southwestern (West and Lux 1993; West 1999) and eastern (Idleman and Ludman 1998; Ludman et al. 1999; Ludman et al. 2000) segments of the NFS suggested that these late events continued sporadically into the Mesozoic. Doll et al. (1996) also inferred Mesozoic (vertical) NFS motion from a seismic reflection profile that shows the Waite fault zone penetrating and offsetting the Moho.

Nine slivers of unmetamorphosed redbeds and associated rocks have been identified along the NFS between Chemo Pond and the New Brunswick border (Fig. 1; Larrabee 1964; Wones 1980; Bradley 1982; Osberg et al. 1985; this study.). The nine include two previously unknown areas discovered during this study, here named the Middle Nicatous Lake basin (between Nicatous and Gassabias lakes) and the Southern Nicatous Lake basin (Fig. 2). These slivers contain granule, pebble, and boulder conglomerate, massive and cross-bedded grey and red arkosic and lithic sandstone, and subordinate amounts of homogeneous dark red mudstone and finely laminated mudstone/siltstone horizons. Clasts in the conglomerate units include low-grade metasedimentary rocks similar to those of the Fredericton and Miramichi belts, rare granite fragments, and large amounts of unmetamorphosed, presumably post-Acadian, red sandstone and mudstone and white to grey arkosic sandstone. The coarse-grained rocks generally occur in very thick beds, implying short transport and rapid deposition within a dynamic continental environment following Acadian orogenesis. 


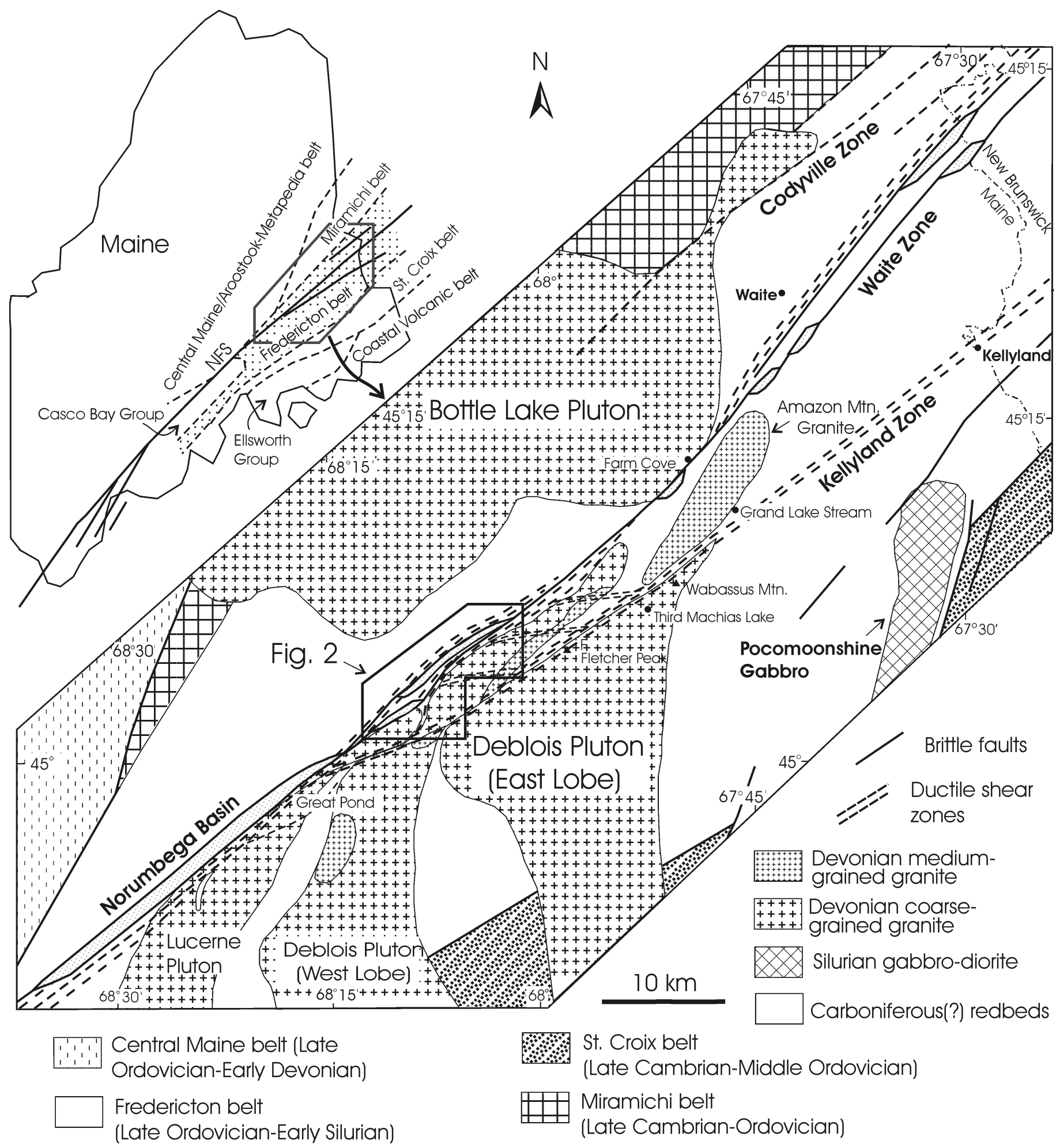

FIG. 1 Regional geologic map showing the Norumbega fault system in eastern Maine. Inset map shows tectonostratigraphic belts distributed in eastern Maine. Mapped and modified based on Osberg et al. (1985).

\section{METHODS}

Detailed mapping and reconnaissance mapping between Amazon Mountain and Nicatous Lake enabled us to refine mapscale relationships within the area where the Waite and Kellyland fault zones converge, improve understanding of relationships among granitic bodies within this area, and identify two new redbed slivers. A detailed digital elevation model for the Great Pond-Kellyland area was composited from $30 \mathrm{~m}$ elevation data for 76 7.5' quadrangles using CARIS GIS software. The model 


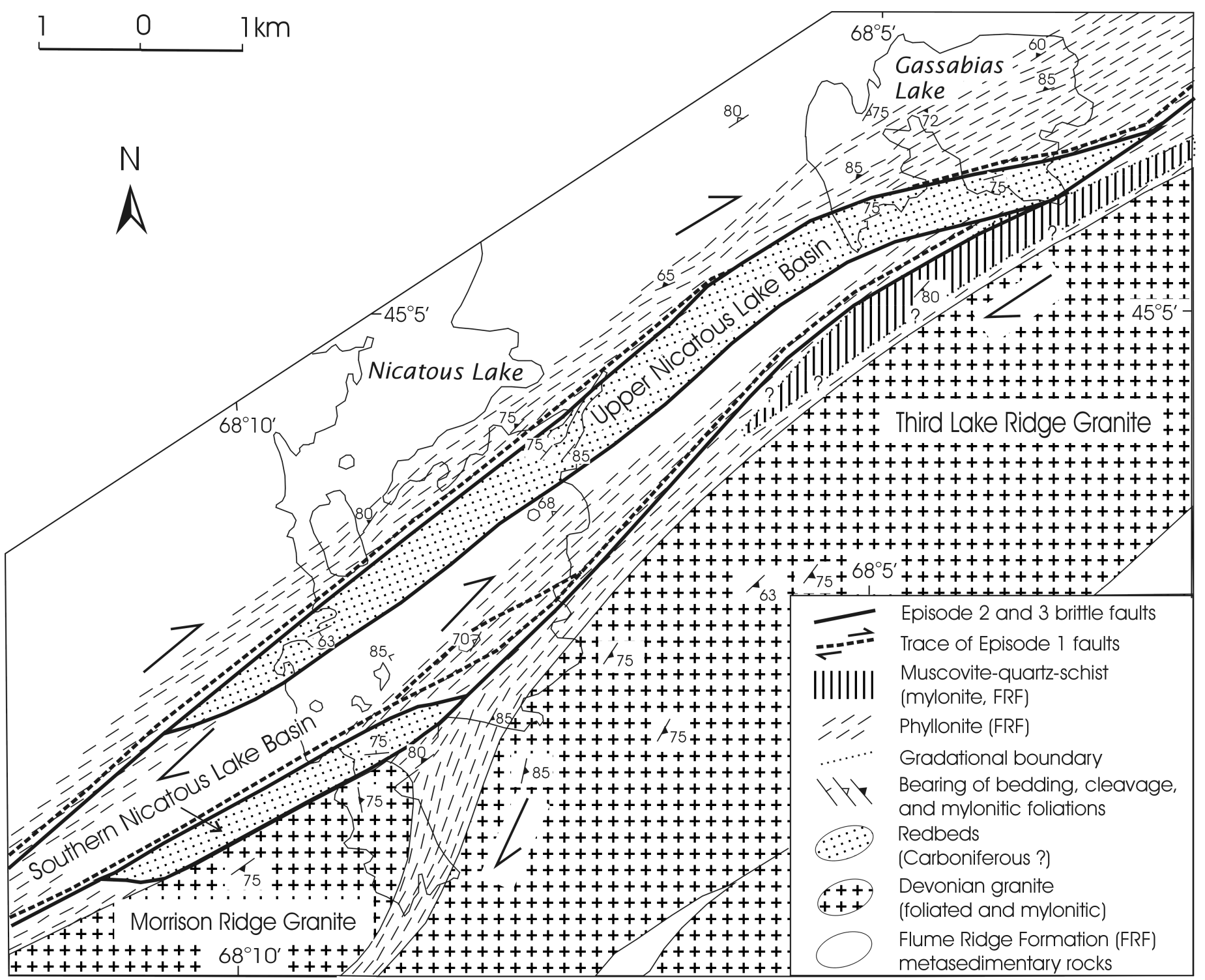

FIG. 2 Structural geologic map showing internal structures of the Waite composite zone in the Nicatous Lake-Gassabias Lake area. See Fig. 1 for location.

reveals splays of Norumbega faults hitherto unsuspected but since confirmed in the field.

The sequence of brittle faulting events was determined from cross-cutting relationships among several sets of outcrop-scale conjugate brittle faults and between these faults and earlier ductile Norumbega fabrics. Bracketing relationships with ductile shear fabrics and the redbed units were used to estimate the timing of the brittle events.

Stress field orientations interpreted for the brittle events are based on Anderson's theory of faulting (Anderson 1951) and Hartman's rule that the maximum principal stress direction bisects the acute angle between conjugate faults. Multiple sets of vertical to near-vertical conjugate faults are particularly abundant in the Waite fault zone and this area became the focus of our detailed analysis, supplemented by additional exposures in the Kellyland shear zone. Care was taken to insure that the conjugate faults measured in the field were indeed systematic Coulomb-
Mohr shear fractures rather than tension cracks. Accordingly, we include in our analysis only those 305 conjugate sets whose members contain slickenlines indicative of fault motion. The conjugate faults that passed this test are within $10^{\circ}$ of vertical, and nearly all of the slickenlines plunge less than $15^{\circ}$, indicating that the maximum principal stresses responsible for the faults were dominantly horizontal.

\section{RESULTS}

Our study has yielded the most detailed map of the granitic plutons, metasedimentary rocks, post-Acadian molasse, and ductile and brittle fault strands yet produced in eastern and east-central Maine (Fig. 1, 2). Improvements and revisions incorporated in this map contribute significantly to understanding the initial ductile Early Devonian phase of Norumbega shearing and will be 
detailed in a separate paper. This paper addresses the brittle history of the NFS, including (1) the roles of the Waite fault zone in regional deformation, (2) the number, nature, and sequence of discrete post-Acadian brittle faulting episodes, (3) the stress fields associated with each episode, and (4) a discussion about the origin of the basins in which the redbeds were deposited.

\section{WAITE COMPOSITE FAULT ZONE}

The Waite fault zone was originally described as the central of three Norumbega high-strain ductile shear zones in eastern Maine (Ludman 1991). It has been mapped continuously for 85 $\mathrm{km}$ northeastward from Great Pond to the Canadian border and continues at least $100 \mathrm{~km}$ farther into central New Brunswick as the Fredericton fault (McLeod et al. 1994). Although the Kellyland and Waite fault zones are distinct strands in eastern Maine, Wang et al. (2000) showed that they merge near Great Pond from whence they continue southwestward in a considerably narrower NFS (Hubbard et al. 1995).

Ludman(1998) showed that the Waite ductile shear zone is cut into slivers in easternmost Maine by anastomosing brittle faults. The zone of ductile shear ranges from a maximum width of $5 \mathrm{~km}$ near the New Brunswick border to $400-500 \mathrm{~m}$ in its narrowest regions, pinching and swelling along strike as a result of the brittle faulting. Our mapping indicated that the Waite fault zone is a complex composite structure resulting from a combination of early ductile shearing overprinted by intense brittle faulting along its entire mapped length.

Despite the shallow crustal level at which deformation occurred, early ductile shearing in the Waite zone generated phyllonite from Fredericton belt pelite and psammite (Ludman 1998) and converted the massive Deblois and Bottle Lake granites to strongly foliated granite, s-c mylonite, and interlayered mylonite and ultramylonite (Wang and Ludman 1999; Wang et al. 2000; Ludman and Gibbons 1999; Ludman et al. 2000). The ductile fabrics are overprinted and offset by abundant brittle structures reported first in the Kellyland fault zone by Ludman and Gibbons (1999).

Several lines of evidence indicate that this Waite composite fault zone is the locus of brittle fault reactivation for the entire NFS: (1) the post-Acadian redbeds crop out solely within the Waite zone; (2) although brittle structures are also present locally in the Kellyland and Codyville fault zones and in the intervening areas, they are most abundant in the Waite zone; (3) Waite zone brittle faults contain the greatest amount of both fine- and coarsegrained cataclasite; (4) map-scale brittle fault offset is restricted to the Waite zone; (5) in contrast, the Kellyland and Codyville zones exhibit only very small-scale brittle structures, typically expressed as narrow $(<5 \mathrm{~cm})$ cataclasite veins within second-order faults.

\section{Relationships within the Waite composite fault zone}

Relationships between ductile and brittle fabrics in the Waite composite fault zone are complex and vary somewhat along strike, but some features are constant within our study area. The northwestern margin of the Waite composite fault zone is typically a gradational contact between undeformed Fredericton belt metasedimentary rocks and their ductilely deformed products - generally phyllonite and sheared metasandstone characterized by penetrative pressure solution cleavage in which clasts are strongly elongated. Biotite and actinolite formed in the higheststrain part of the Waite ductile shear zone.

Brittle effects are most pronounced along the southeastern margin of the composite fault zone in the area between Waite and the Maine-New Brunswick border and in the Nicatous Lake area. In both locations, the early-stage phyllonite is juxtaposed against post-Acadian redbeds or metasedimentary rocks of the Fredericton belt that exhibit little evidence of ductile strain. Details of brittle strain zonation will be presented below. Anastomosing brittle fault strands carve the phyllonite into lenses, convert it to cataclasite, and retrograde the biotite and actinolite to chlorite. Relict phyllonitic foliation in adjacent lenses is typically discordant, suggesting that they have rotated relative to one another during the brittle faulting. The originally near-vertical phyllonitic foliation is locally folded and flattened to sub-horizontal attitudes.

\section{MULTIPLE BRITTLE REACTIVATION IN THE NORUMBEGA FAULT SYSTEM IN EASTERN MAINE}

Cross-cutting relationships among outcrop-scale faults and conjugate fault pairs in the Waite composite fault zone and Kellyland zone permit recognition of three distinct episodes of compressional brittle faulting, episodes 1,2, and 3, that followed a ductile-brittle transitional event between early ductile shearing and episode 1 of completly brittle deformation. Each episode was characterized by a different maximum principal stress $\left(\sigma_{1}\right)$ direction and sense of motion (Figs. 3, 4, 5). Cross-cutting relationships among narrow cataclasite zones and small-scale second-order conjugate fault pairs associated with these events enabled us to establish their sequence.

\section{The Ductile-Brittle transition}

Near-vertical outcrop-scale conjugate faults have been identified within the sheared Deblois granite along the Kellyland ductile shear zone that exhibit a combination of ductile and brittle features. These small faults are superimposed on granitic mylonite generated by early ductile shearing and are cut by all other brittle structures and fractures. In the Wabassus Mountain area, they also cut and offset fine-grained granitic dikes. One fault set of this brittle/ductile conjugate system strikes at around $010^{\circ}$ and the other at around $050^{\circ}$. All displacement indicators show that the former set is sinistral and the latter dextral, demonstrating that the maximum principal stress is in the direction of about $120^{\circ}$. Obviously the maximum principal stress orientation bisects the obtuse angle between two sets, suggesting ductile deformational mechanisms consistent with the following observations.

This conjugate system generated outcrop-scale ductile-brittle faults $2 \mathrm{~cm}-1.5 \mathrm{~m}$-wide, most commonly several centimetres. 
FIG. 3 Distribution, strike rose diagram, and equalarea stereogram of measured conjugate faults and deduced maximum principal stress orientations $\left(\sigma_{1}\right)$ of episode 1 faulting in the area between Great Pond and Grand Lake Stream. Stereogram shows poles to conjugate faults (open circles) and $\sigma_{1}$ (dots) for each measured pair of conjugate faults. Stars are projection of small-scale asymmetric fold hinges.

FIG. 4 Distribution, strike rose diagram, and equal-area stereogram of measured conjugate faults and deduced maximum principal stress orientations $\left(\sigma_{1}\right)$ of episode 2 faulting in the area between Great Pond and Grand Lake Stream. Stereogram shows poles to conjugate faults (open circles) and $\sigma_{1}$ (dots) for each measured pair of conjugate faults.
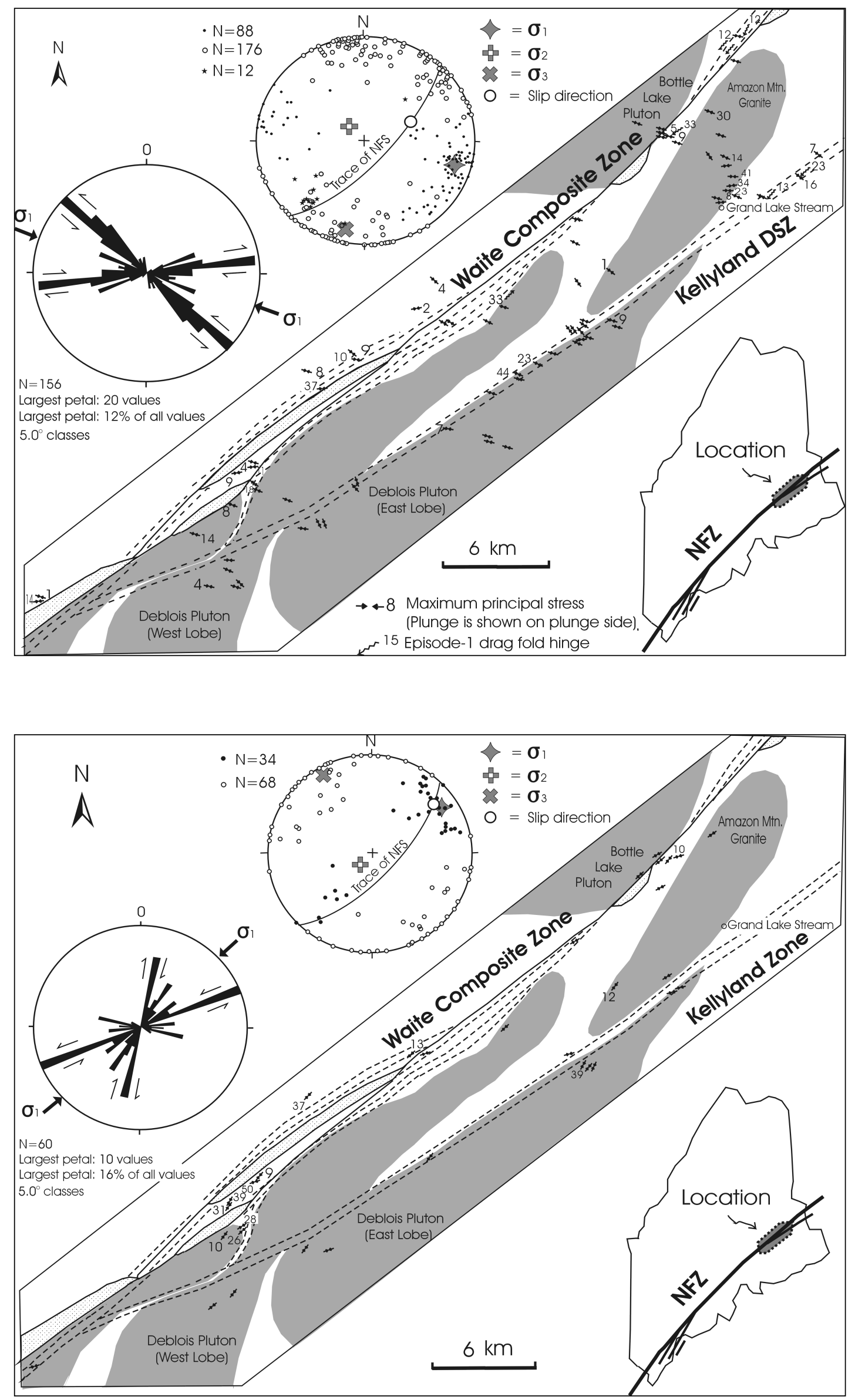
The faulted rocks are partly mylonitic and partly cataclastic. The ductile-brittle faults are fundamentally ductile, meaning that the feldspar crystals are elongated and the quartz grains plastically deformed and ribboned to become banded or laminated mylonite, and that abundant features of plastic deformation have been seen within quartz grains. However, at least one side of each mylonite zone has a sharp and straight fault contact, and the change from this mylonite to unaffected rocks is so abrupt that only brittle fracturing is likely to have been responsible for this relationship. In fact, these contacts are generally delineated by very narrow bands of cataclasite. It is also common for the offset fine-grained granitic dikes to show drag folding, but they are abruptly broken at the contacts. According to Ramsay and Huber (1983) and Davis and Reynolds (1996), such small-scale fault zones are best defined as brittle-ductile faults. They most likely began as continuous ductile shear zones but developed sharp, fault-like features along their margins when the physical conditions changed during deformation.

The maximum principal stress orientation (about $120^{\circ}$ ) deduced from this brittle-ductile conjugate system is about the same as that from the episode 1 small-scale conjugate system discussed next, implying that they were generated under similar dynamic environments. We ascribe the ductile-brittle transitional event to the precursor or the early phase of episode 1 brittle reactivation.

\section{Episode 1: Dextral-oblique-reverse faulting}

A broad, continuous zone of cataclasite and breccia crops out along the Waite composite fault zone, indicating that the older Waite ductile shear zone was reactivated during later brittle activity (Fig. 6a, 6b). Two other sets of brittle structures in the Waite composite fault zone overprint this cataclasite and breccia zone (see below). Therefore it is believed that this zone represents the earliest episode of brittle faulting, here termed episode 1 . In contrast, only minor cataclasis and brecciation were found in granite, granitic mylonite, and phyllonite in the Kellyland ductile shear zone.

For the most part, the episode 1 brittle fault zone followed the pre-existing Waite ductile shear zone (Fig. 1,2), affecting the Flume Ridge Formation, granite of the Bottle Lake pluton, and ductilely-faulted rocks produced during early ductile shearing. Faults associated with episode 1 brittle activity have not been recognized in the redbeds. In the Nicatous Lake-Gassabias Lake area, the Waite ductile shear zone has an anastomosing nature and branches locally into two major sub-zones (Fig. 2). Both sub-zones were reactivated during the episode 1 event, with mappable cataclasite and breccia belts. Brittle fabrics dip steeply $\left(65-75^{\circ}\right)$ to the southeast. The more competent siltstone layers and quartz veins in Flume Ridge phyllonite and metasedimentary rocks are boudinaged, and the boudin arrays also dip southeast at about $65-75^{\circ}$, as do the fault displacement surfaces. These features suggest that the master brittle episode 1 fault dips steeply to the southeast.

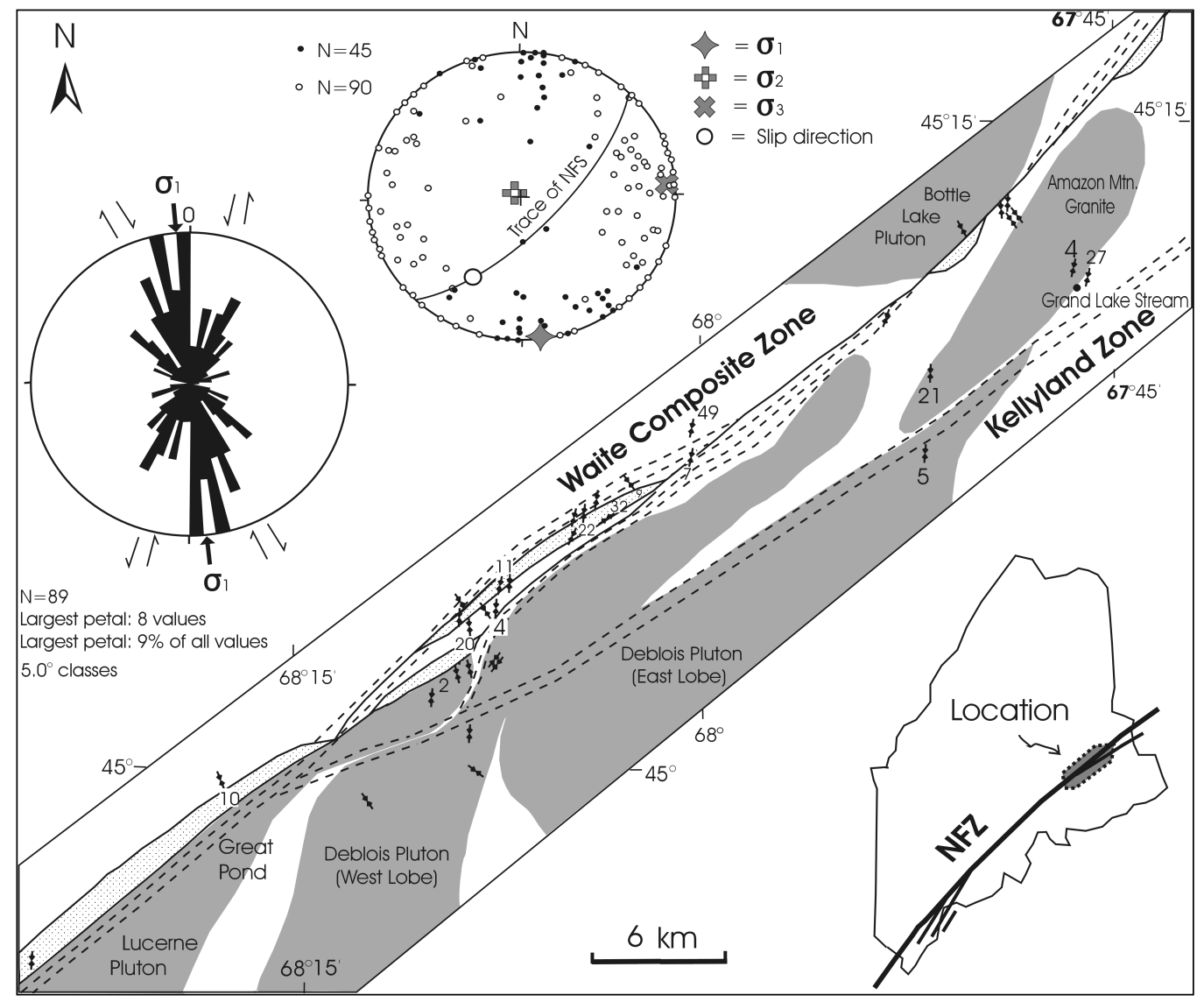

FIG. 5 Distribution, strike rose diagram, and equal-area stereogram of measured conjugate faults and deduced maximum principal stress orientations $\left(\sigma_{1}\right)$ of episode 3 faulting in the area between Great Pond and Grand Lake Stream. Stereogram shows poles to conjugate faults (open circles) and $\sigma_{1}$ (dots) for each measured pair of conjugate faults. 
$\bar{b} \downarrow$
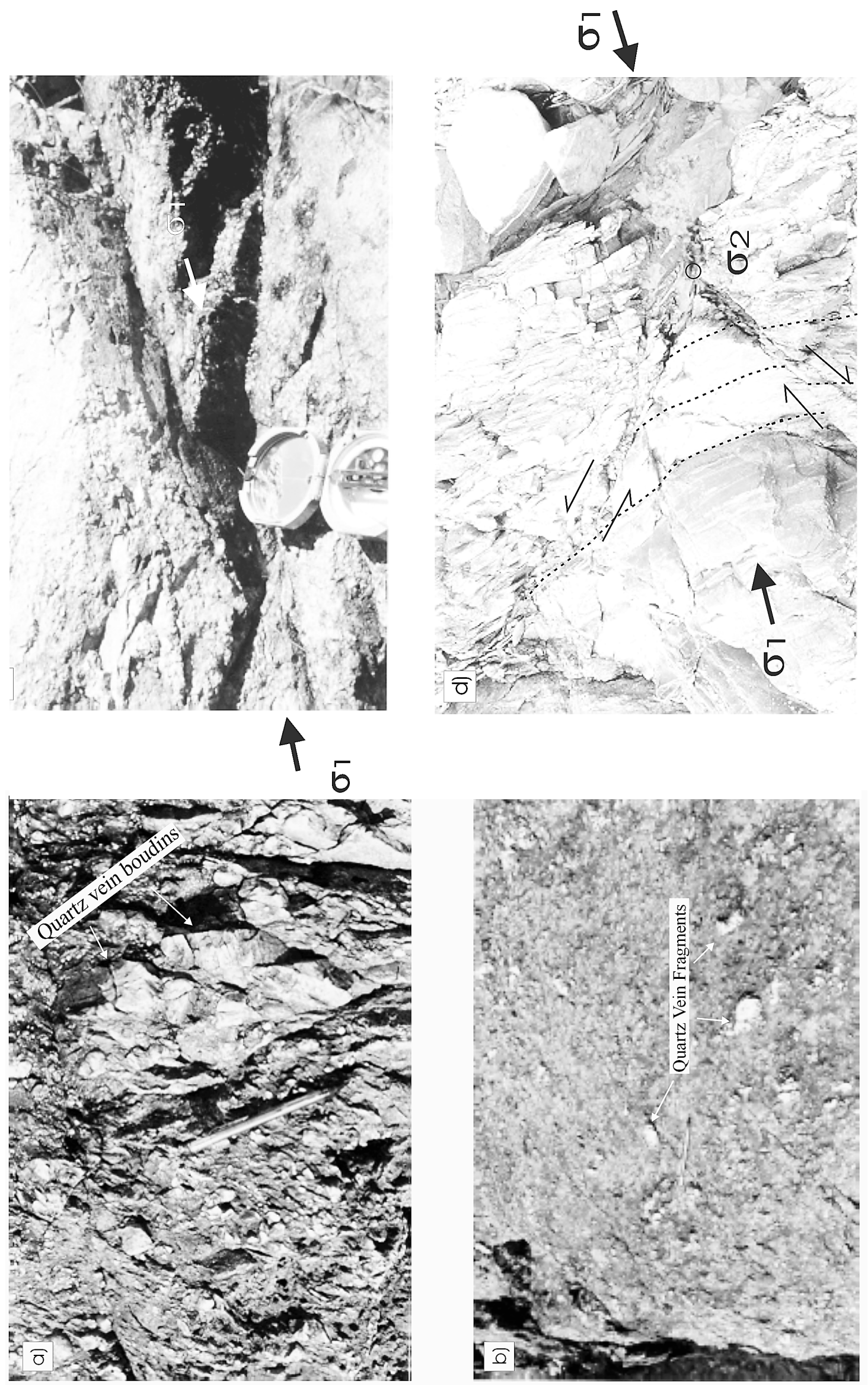


\section{Episode 1 zonation}

As mentioned above, episode 1 brittle faulting followed the pre-existing Waite ductile shear zone between Great Pond and the New Brunswick border where most of the Waite zone is hosted by the Flume Ridge Formation. Its metasedimentary rocks and the phyllonite generated from them during early ductile shearing have been brecciated, cataclased, boudinaged, and fractured.

The brittle component of the Waite composite fault zone is well zoned, with a central chaotic belt flanked by progressively more coherent packages that have been broken but remained essentially coherent. The central part of the brittle component is a 50-m wide belt of cataclasite and breccia that represents the greatest brittle strain in the Waite zone (Fig. 6a, 6b). Fabrics range from cataclastic to chaotic, with nearly all bedding, foliation, and quartz veins or boudins completely destroyed. Intensely fractured bands of Flume Ridge Formation rocks more than 50 $m$ wide symmetrically flank this central cataclasite/breccia belt. Within these less intensely deformed belts, bedding and ductile shear foliation are well preserved but typically cross-cut by joints. The transition from the central belt to the less fractured belts that flank it is gradational, and lenses of high-strain chaotic fabric are well preserved within more coherent materials in the transition to the outer zones.

Episode 1 brittle zonation is very well exposed south of West Grand Lake in the Grand Lake Stream quadrangle near Big Mayberry Cove and the Farm Cove dam. There, the Waite cataclasite and breccia zone separates the Flume Ridge Formation from the Bottle Lake pluton. The coarse-grained granite at the contact is intensely fractured to become typical granitic cataclasite and exhibits the highest brittle shear strain observed in the Waite zone. This zone of granitic cataclasite is at least $35 \mathrm{~m}$ wide and is best exposed on the southeastern side of the dam and at Big Mayberry Cove. Fine calcite veins and minor chlorite veins are common in cataclasite throughout the fault, and cut early foliation and fill cracks and fissures, suggesting association with the cataclasis.

\section{Kinematics}

Episode 1 brittle faulting produced outcrop- and specimenscale asymmetric folds that are best exposed east of Waite and north of Amazon Mountain. Phyllonitic foliation is folded with hinges that plunge gently $\left(10^{\circ}-15^{\circ}\right)$ to the southwest. They are asymmetric (Z-shaped when viewed down-plunge) with southeastward-dipping axial-plane surfaces and indicate a southeast-

FIG. 6 (Left) (a) and (b) are photographs of faulted rocks breccia (a) and cataclasite (b) generated by episode 1 brittle faulting in the Flume Ridge metasedimentary rocks in the Waite fault zone. (a) is at south side of Fourth Machias Lake and (b) southern Nicatous Lake. (c) shows near-horizontal slickenlines shown on episode 1 conjugate fault surfaces in Amazon Mountain granite, Grand Lake Stream. (d) shows episode 1 conjugate faults in metasedimentary rocks, Kellyland Dam. Big arrows indicate inferred maximum principal stress orientations. All are plan view. side-upward movement, i.e. a reverse motion. Slickenlines on some anastomosing fault surfaces also indicate dominantly dip-slip movement. Compressional tectonic boudin lenses with near-horizontal necklines are developed within the transition zone from cataclasite/breccia to fractured/jointed rock. These and other kinematic indicators suggest that episode 1 was an episode of dextral-oblique-reverse brittle faulting along the Waite zone.

\section{Principal stress analysis}

The system of small-scale conjugate faults attributed to episode 1 reactivation has been observed in metasedimentary and granitic rocks along the fault system, one set striking around $080^{\circ}$ with dextral displacement and the other $130^{\circ}$ with sinistral displacement (Fig. 3, 6c, 6d). Some conjugate kink bands have also been observed in pelite and interbedded wacke. Development of some small valleys or streams was obviously controlled by these two sets, e.g. on the northwest side of Washington Bald Mountain and cliffs such as Fletcher Peak, Horseshoe Mountain, Eagle Mountain, and parts of Slewgundy Ridge and Knox Mountain in the Fletcher Peak area.

Numerous narrow ( $5 \mathrm{~cm}$ wide) cataclasite bands were generated within these conjugate faults, most commonly in granite, but also within some metasedimentary rocks. Some conjugate faults exhibit an en echelon pattern (Fig. 7), and some in granite are filled by epidote veins. Offset in individual episode 1 conjugate faults is commonly around $30-50 \mathrm{~cm}$. The largest measured displacement is $20 \mathrm{~m}$ in a dextral fault striking $080^{\circ}$ in the phyllonite zone on the eastern side of Third Machias Lake. Most of these conjugate faults contain slickenlines that plunge gently northeastward on the $080^{\circ}$ set and at $1^{\circ}-15^{\circ}$ southeastward on the $130^{\circ}$ set, imply-

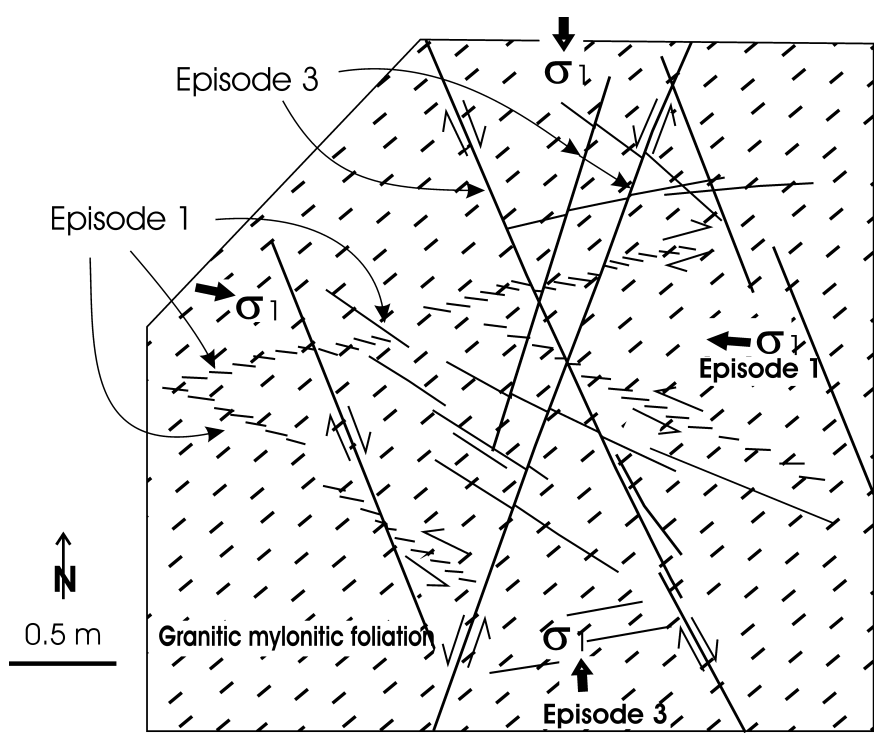

FIG. 7 Sketch showing episode 1 conjugate faults and en enchelon fractures cut by episode 3 conjugate faults in the foliated Deblois granite. Short black arrows point to maximum principal stress directions, Wabassus Mountain. 
ing a nearly horizontal compressional maximum principal stress (plunge slightly to the southeast; Fig. 3, 6c).

The trend of the maximum episode 1 compressive principal stress $\left(\sigma_{1}\right)$ is interpreted from these small-scale conjugate faults to average $115^{\circ}-125^{\circ}$ (Fig. 3), at an average angle of $70^{\circ}-80^{\circ}$ with faults of the Norumbega fault system. The kinematics discussed above suggest that brittle episode 1 reactivation involved mostly dip-slip motion with a slight dextral strike-slip component. Therefore, it is likely that the episode 1 brittle reactivation was a reverse motion. The compressive fabrics and tectonic lenses observed in episode 1 brittle zones also suggest a compressional environment. Reactivation of the Waite fault zone during episode 1 is therefore interpreted as an event of dextral-oblique-reverse faulting, consistent with Swanson's oblique convergence model for the Norumbega system (Fig. 12 in Swanson 1999). However, the fact that the intermediate principal stress deduced from smallscale episode 1 conjugate faults is nearly vertical (Fig. 3) suggests that reverse faulting is unlikely. Reverse faulting in such a stress regime (Fig. 3) can only take place when the intermediate principal stress is equal or nearly equal to the minimum principal stress (Davis and Reynolds 1996).

Angelier (1984) found that the intermediate and minimum stresses are about equal in many orogenic belts. In the Quebec and northern New Brunswick Appalachians, Faure et al. (1996) identified three compressive tectonic events after a numerical paleostress tensor analysis using striated fault planes. All three paleostress fields had very similar $\sigma_{2}$ and $\sigma_{3}$ magnitudes compared to $\sigma_{1}$. Correlation of these fault events with those reported in this study will be discussed below, but the results reported by Faure et al. (1996) suggest that the episode 1 compressive stress field in eastern Maine may also have had very similar $\sigma_{2}$ and $\sigma_{3}$ magnitudes, thereby facilitating the reverse reactivation of the Waite fault zone postulated above. Steeply-dipping reverse-slip faults (typically dipping $60^{\circ}$ or more) are common and accommodate crustal shortening in orogenic belts around the world. Most of them are also interpreted as a result of fault reactivation, i.e., preexisting steeply-dipping faults are reactivated as reverse-slip faults (Davis and Reynolds 1996).

Angelier (1994) emphasized that the actual rake of slip along a reactivated fracture or fault surfaces depends on the magnitude of the intermediate principal stress relative to that of the maximum and minimum principal stresses. He also demonstrated that the slip direction may be parallel to the direction of maximum shear stress resolved along the preexisting fracture surface. With Angelier's method, slip directions on preexisting fault surfaces can be determined stereographically. The slip direction on the preexisting Waite zone for episode 1 brittle reactivation determined in this way is consistent with the kinematic and dynamic analysis results presented earlier (Fig. 3).

\section{Episode 2: Dextral strike-slip faulting}

Faults attributed to a second reactivation of the Waite zone (brittle episode 2) offset those of episode 1 and are themselves overprinted by faults assigned to episode 3 (Fig. 8). Episode 2 structures are concentrated geographically along the episode 1

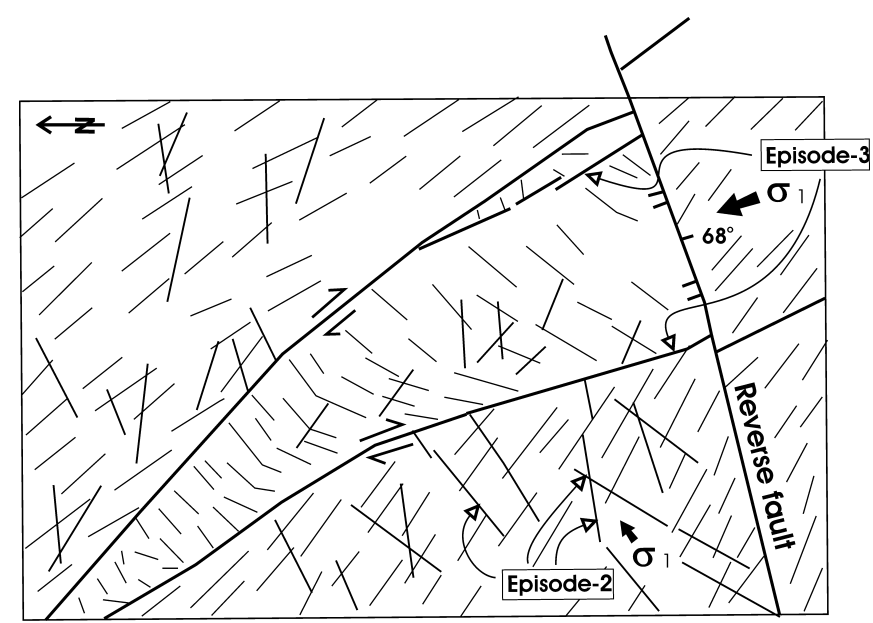

FIG. 8 Episodes 2 and 3 conjugate faults in Flume Ridge phyllonitic metasedimentary rocks in Kellyland zone. Line drawings from photography. Northeast side of Third Machias Lake.

master faults, but occur in much narrower zones only a few centimetres to metres wide. Like brittle faults of episode 1, they affected metasedimentary, granitic, and ductilely sheared rocks but have not been observed in the redbeds.

\section{Kinematics}

The narrowness of episode 2 fault zones and sparse exposures severely limit direct observation of kinematic indicators comparable to those seen in the broad episode 1 fault zone. As a result, episode 2 is reconstructed solely through its small-scale conjugate faults.

\section{Principal stress analysis}

The episode 2 conjugate system typically has a set of dextral faults oriented around $010^{\circ}-020^{\circ}$, and a sinistral set oriented $060^{\circ}-070^{\circ}$ (Fig. 4). More easterly attitudes were found in the Nicatous Lake-Gassabias Lake area where the Waite zone splits into two sub-zones that merge again on the eastern side of Gassabias Lake, forming a fault-bounded block $10 \mathrm{~km}$ long and $1 \mathrm{~km}$ wide (Fig. 2). Next to this block on the southeast, the Third Lake Ridge granite sliver appears to have acted as a rigid block that caused the local stress field to change slightly. In this area $\sigma_{1}$ rotated easterly, generating a locally well-developed conjugate fault system with one dextral set of faults oriented around $050^{\circ}$ and a sinistral, set around $080^{\circ}$. Slickenlines on the conjugate fault surfaces are generally sub-horizontal, proving again that the maximum principal stress orientation was sub-horizontal. The maximum principal stress $\left(\sigma_{1}\right)$ deduced from episode 2 conjugate structures is oriented $045^{\circ}-075^{\circ}$ (Fig. 4), making a small angle (average $15^{\circ}$ ) with the trace of the inferred master fault. This relationship probably caused dextral strike-slip movement along the pre-existing Waite brittle fault zone. The slip direction for episode 2 brittle reactivation based on Angelier's method supports this assertion, showing nearly horizontal slip (Fig. 4). 
Episode 2 dextral strike-slip faulting is believed to be responsible for the formation of the redbed basins along the length of Waite zone and will be discussed separately later.

\section{Episode 3: Reverse-sinistral (oblique) faulting}

Small-scale faults of episode 3 cut metasedimentary, granitic, and ductile fault rocks, and also overprinted episode 1 and episode 2 faults and cataclasite zones (Fig. 7, 8). In contrast to features associated with episodes 1 and 2, episode 3 faults also cut conglomerate, sandstone, and mudstone in the post-Acadian redbed slivers. Mapping during this study and by previous workers showed that the redbeds are everywhere in fault contact with granite, metasedimentary rocks, mylonite, or phyllonite, and that these rocks are steeply tilted with variable dip directions along those faults. These faults are considered to be map-scale examples of episode 3 brittle structures.

\section{Kinematics}

Post-Acadian redbeds in the "Norumbega basin" (Bradley 1982), and the Middle Nicatous Lake, and Southern Nicatous Lake redbed basins identified during this study (Fig. 1, 2), strike around $065^{\circ}-090^{\circ}$ and dip steeply at $75^{\circ}-90^{\circ}$. Based on the reversals of SE- and NW-dipping beds, a series of tight upright anticlines and synclines is inferred with axes trending around $065^{\circ}-090^{\circ}$. These folds are now recognized in all of the redbed slivers along the Waite fault zone where bedding has been observed. The axes of the folds make an angle of $20^{\circ}-45^{\circ}$ with the fault system, implying that there might have been sinistral strike-slip movement, but the reversals could be explained if the redbeds occurred in variably tilted, fault-bounded slivers.

\section{Fault dynamics and principal stress analysis}

Small-scale episode 3 conjugate faults include a sinistral set striking around $010^{\circ}-020^{\circ}$ and a dextral set oriented $160^{\circ}-170^{\circ}$ (Fig. 5). From these attitudes, $\sigma_{1}$ for brittle episode 3 is estimated to be around $165^{\circ}-190^{\circ}$ (Fig. 5, 7 and 8), suggesting that this third brittle reactivation along the Waite composite fault zone was oblique with both sinistral strike-slip and reverse components. The determination of the slip direction on the preexisting Waite zone for episode 3 brittle reactivation with Angelier's method is shown in Fig. 5, and also suggests oblique motion.

In addition, a third set of small-scale secondary faults has been observed in the redbeds in the Nicatous Lake area and in the Flume Ridge metasedimentary rocks (Fig. 8), striking $099^{\circ}-110^{\circ}$ and dipping gently to the north. This set shows reverse or thrust motion based on offset markers and inclined slickenlines observed on the fault surfaces. This observation implies north-south compressional stress, agreeing with the $\sigma_{1}$ direction deduced from episode 3 conjugate faults.

The inferred oblique movement juxtaposed the redbeds against older Fredericton belt rocks and was responsible for the current steep dip (mostly around $75^{\circ}-90^{\circ}$ ) of the red conglomerate and sandstone beds. The axes of the inferred tight upright anticlines and synclines developed in the Norumbega and middle Nicatous Lake basins are roughly perpendicular to the orientation of the maximum principal stress, supporting the reverse-sinistral-strikeslip kinematics and fault dynamics deduced from the small-scale structures. However, most steeply dipping beds in the smaller basins (Fig. 1) strike around $035^{\circ}-055^{\circ}$ and typically parallel the bounding faults. This may have been caused by sinistral strike-slip movements in which bedding was easily rotated toward and finally into parallelism with the faults in these much smaller basins.

\section{TIMING OF BRITTLE FAULTING IN THE WAITE COMPOSITE FAULT ZONE}

Nearly all of the small-scale brittle faults used in this study cross-cut ductile fabrics generated during early Norumbega shearing in the granite plutons and Fredericton belt metasedimentary rocks and therefore post-date the initial phase of Norumbega faulting. The sole exceptions are where episode 3 faults affect the redbeds from which the ductile fabrics are absent. Consistent cross-cutting relationships among these features enabled us to decipher the sequence of brittle events described above and serve as a model for interpreting reactivated brittle faulting along the entire Norumbega fault system.

The precise timing of the three brittle faulting episodes cannot be determined directly because no new mineral phases crystallized during these events. Radiometric ages of the granites and early ductile fabrics provide a maximum age but there is little constraint on how young the last episode might have been. The absence of episodes 1 and 2 structures from the redbeds and the presence of episode 3 faults throughout all rock types in the Waite composite fault zone indicate that redbed deposition separates episodes 1 and 2 from episode 3.

Unfortunately, there is little control on the timing of redbed deposition, leaving their age and that of the brittle deformation events uncertain. As neither macro- nor microfossils have been found in the redbeds, their age can be inferred only by structural position and regional correlation. Analogous post-Acadian molasse ranges from as old as Late Devonian (the Perry Formation of southeasternmost Maine) to as young as Mississippian and Pennsylvanian in the large Carboniferous basins of Maritime Canada and the Plaster Rock outlier in northwestern New Brunswick. In addition, an unknown but probably significant amount of time must have separated the Middle Devonian (380 $\mathrm{Ma}$ ) ductile shearing event from redbed deposition. During that span, episode 1 brittle faulting occurred, followed by erosion of Acadian metasedimentary and granitic rocks to form first-cycle pale grey to white molasse. There must also have been enough time for the first-cycle molasse to be lithified completely, uplifted, and eroded, and its fragments added to the second-cycle red molasse beds found today along the Waite and Fredericton faults.

A Pennsylvanian age is preferred for the redbeds to allow sufficient time for the two-cycle erosion/deposition history inferred for these rocks, and because redbed slivers in the Waite composite zone are along strike with Pennsylvanian counterparts along the Fredericton fault, the continuation of the Waite zone in New 
Brunswick, whereas the Perry basin is located more than $60 \mathrm{~km}$ across strike to the southeast. A Pennsylvanian (?) age will be assumed in the following discussions, to avoid overly complex wording, with the caveat that this is by no means certain.

Episode 1 brittle reactivation is bracketed between the 380 Ma age of the ductile fabrics that it overprinted and the age of the redbeds. Episode 2 may have played a role in opening the basins in which the first-cycle molasse was deposited (see below); reactivation of these faults is thought to have provided the depocenters for the second-cycle redbeds. Middle to Late Devonian and Mississippian ages are considered most likely, respectively, for these two events, but cannot be proven.

Episode 3 obviously followed deposition of the redbeds. If the redbeds were indeed deposited in the Pennsylvanian, a late- or post-Carboniferous age is required. Because episode 3 was compressional in nature, it is not likely to have been associated with the early Mesozoic rifting that led to the opening of the Fundy basin and the modern Atlantic Ocean. This observation suggests that episode 3 activity was bracketed between the Pennsylvanian (?) deposition of the redbeds and the onset of extensional block faulting in the Triassic - i.e., episode 3 is the best evidence for the Alleghenian orogeny in this part of eastern Maine.

\section{CORRELATION OF NORUMBEGA FAULTING WITH REGIONAL OROGENIC EVENTS}

Based on the timing deduced for the ductile (Ludman et al. 2000; Wang et al. 2000) and brittle activity in the study area, and on the paleostress analyses for the late-stage episodes of brittle faulting, it is possible to correlate the Norumbega faulting activities investigated in this study with major tectonic events in the Appalachian orogen.

\section{Early ductile shearing - Late Acadian plate adjustments}

The oldest shearing recognized in the Norumbega fault system in eastern Maine occurred in the Middle Devonian ( 380 Ma), and is attributed to late-stage activity associated with the Acadian orogeny (West and Hubbard 1997; Ludman et al. 1999). West et al. (1992) demonstrated that the climax of Acadian deformation in the Fredericton belt was late Silurian. Bradley et al. (1998) showed that the Acadian event was regionally diachronous, beginning in eastern Maine in late Silurian time and becoming progressively younger (to Middle Devonian) in central and north-central Maine. The Early Devonian phase in easternmost Maine was explained by Bradley et al. (1998) as the result of a "tectonic backstop". Thermal adjustments to Acadian tectonism led to melting and emplacement of numerous Devonian plutons such as the Bottle Lake, Deblois and Lucerne, and continued adjustment of plates whose oblique collision caused the Acadian orogeny led to the dextral ductile shearing.

The timing and dextral sense of motion associated with the ductile shearing are thus consistent with the timing and kinemat- ics of plate collision generally interpreted for the Acadian orogeny (e.g., Bradley et al. 1998; Gates et al. 1988).

\section{Brittle episodes 1, 2, and 3: post-Acadian - Alleghanian transition}

Paleostress analyses described earlier yielded different major compressive stress directions for the three post- $380 \mathrm{Ma}$, brittle Norumbega faulting episodes in eastern Maine. $\sigma_{1}$ for the earliest (episode 1) and most intense event was oriented approximately WNW-ESE, but rotated to NE-SW for episode 2 and changed drastically to N-S for episode 3 . These paleostress results share some similarities with those from other segments of the Appalachian orogen but also contain significant differences, both in orientation and time.

In Quebec and northern New Brunswick, ductile fabrics comparable to those of the Kellyland and Waite fault zones are absent, but similar small-scale conjugate sets of reverse and strikeslip brittle faults are abundant (Faure et al. 1996). A numerical paleostress tensor analysis of striated fault planes by Faure $e t a l$. (1996) identified stress fields associated with three distinct brittle compressional events. The earliest and most intense had $\sigma_{1}$ oriented NNW-SSE, $\sigma_{1}$ for the second was NNE-SSW, and $\sigma_{1}$ for the last was WNW-ESE. Interestingly, the third compressive event in Quebec, like episode 3 in the study area, is also mostly recorded in Carboniferous rocks although its maximum stress direction is oriented differently from that inferred along the Waite composite zone.

Faure et al. (1996) described a counterclockwise rotation of compressional axes in the Quebec and northern New Brunswick Appalachians. A counterclockwise rotation of compressional axes from episode 1 to episode 2 in eastern Maine is in this respect consistent with their results. The ages of faulting, however, are not. Faure et al. (1996) suggested that the first two compressional events in the Quebec Appalachians took place during Late Carboniferous to Early Permian and the third from Early to Late Permian time, and are the principal results of the Alleghanian orogeny in the region. Because episodes 1 and 2 in eastern Maine predated deposition of Pennsylvanian (?) redbeds, they cannot be related to Alleghanian compression and most likely predate all three events described by Faure et al. (1996). Only episode 3 is potentially young enough to correlate with the features reported by Faure et al. (1996). Based on similar stress field orientations, episode 3 appears to correlate best with the first Alleghanian compressional event in Quebec and northern New Brunswick.

Farther south, analysis of joint distributions and layer-parallel shortening fabrics in the Appalachian foreland sequence reveals two main directions of compression; an older one oriented northsouth and a younger oriented WNW-ESE (Engelder and Geiser 1980; Dean et al. 1988; Evans 1994). In the northern part of the Appalachian Plateau, two sets of joints oriented NNW-SSE and NNE-SSW were attributed, respectively, to the Lackawana phase and to the main phase of the Alleghanian orogeny (Engelder and Geiser 1980). In the central Appalachian foreland, both northsouth and WNW-ESE shortening directions have been reported 
(Dean et al. 1988; Evans 1994). Further south in the central Appalachian Plateau in Virginia, Dean et al. (1988) also found an earlier compression axis oriented between $330^{\circ}$ and $350^{\circ}$ that was followed by a progressive counterclockwise rotation of the compressional axis to $275^{\circ}$. Limestone of the Appalachian Plateau and of the Hudson River Valley also records NS- and WNW-ESEoriented compressive directions (Craddock et al. 1993; Sierra et al. 1993).

If the ages inferred for episodes 1 and 2 are correct, it appears that these events record a previously poorly-known part of northern Appalachian history - the transition from Acadian stress regimes related to one set of plate collisions to Alleghanian stresses associated with very different plate interactions. Effects of Alleghanian deformation in the study area are probably restricted to episode 3.

\section{Origin of the redbeds in east-central and easternmost Maine}

The origin of the nine narrow redbed slivers along the length of the Waite composite fault zone has seldom been mentioned by previous workers and is problematic, with three likely scenarios:

1) The redbeds were originally part of an extensive postAcadian molasse sheet, possibly connected to similar rocks in New Brunswick. Post-depositional dip-slip faulting could have downdropped and therefore preserved the slivers, while uplifting the remainder of the sheet and leading to its erosion. Larrabee (1964) mentioned this possibility but without any further discussion.

2) An episode of brittle faulting following episode 1 could have formed small pull-apart basins in which the rocks were deposited. Pull-apart basins comparable to those envisaged in this second model are common along major strike-slip faults throughout the world (Burchfiel and Stewart 1966). Bradley (1982) mentioned the possible pull-apart mechanism for the "Norumbega basin" (Fig. 1) but without a detailed explanation.

3) The third possibility, not mentioned by previous workers, is that the redbeds were deposited in grabens or half grabens generated by extensional deformation along the fault system.

This study strongly favours the second scenario, the strike-slip pull-apart model, and suggests that all the redbeds were deposited in pull-apart basins generated by episode 2 dextral strike-slip faulting. This conclusion is based on the following observations and arguments:

1) Rocks in the nine individual redbed slivers do not fit readily into a simple facies model, and each sliver possesses its own, slightly to distinctly different, stratigraphic package. This difference does not disprove the molasse sheet model as rapid facies changes would be expected in a complex intermontane fluvial system, but does raise some questions and keeps the second model in contention.

2) All the redbed slivers now have elongate, narrow shapes and are bounded by brittle faults of the Waite composite fault zone. No other similar rocks have been found outside of the Norumbega fault system in east-central and eastern Maine. This observation implies that the redbeds were associated with brittle faulting. If the first model were valid, the redbed slivers would have to have been down-dropped in the Waite fault zone while the rest of the broad molasse sheet would have been uplifted and completely eroded all around the Waite fault zone. This situation is very unlikely as there is no evidence of post-episode-1 dip-slip fault events with appropriate kinematics to have down-dropped the redbed slivers anywhere along the Norumbega fault system in eastern Maine. Brittle episode 3, the only brittle faulting event that affected the redbeds, was compressional and oblique according to this study. It deformed the redbeds but did not down-drop them. The Fredericton fault in New Brunswick offsets the Carboniferous redbeds, but no significant vertical motion has been reported there either, therefore the first model should be discarded.

3) Previous studies of post-Acadian molasse in New Brunswick, Nova Scotia, and Prince Edward Island show that these rocks were deposited in large Carboniferous continental redbed basins that initiated as independent pull-apart basins (e.g. Bradley 1982, 1988). Bradley $(1982,1988)$ proposed that these basins, all associated with orogen-parallel transcurrent fault systems in the northern Appalachian orogen, formed as a result of pull-apart activity. The Norumbega fault system is one of these transcurrent fault systems. The late Devonian-early Carboniferous rhomboidal Magdalen pull-apart basin, located in the Gulf of St. Lawrence, was believed to have been generated by dextral strike-slip movement along the Fredericton fault (Bradley 1982, 1988), the northeastern extension of the Norumbega fault system in New Brunswick. Therefore the same pull-apart mechanism could also have occurred farther to the southwest, along the Maine segment of the fault system.

4) No regional scale extensional structures have been observed along the Norumbega fault system in eastern Maine, suggesting that third model cited above is not appropriate. This study suggests that the kinematics of episode 2 are consistent with the pullapart fault basin model. A strike-slip movement regime with local extensional environments is indicated if the redbeds were initially deposited in fault-bounded pull-apart basins. Episode 1 could not have been the basin-forming event, because of its oblique compressional nature described earlier. Small-scale faults associated with episode 2 structures have not been identified in any of the redbed slivers, suggesting that it predated or perhaps was synchronous with their deposition. Episode 2 also experienced the dextral strike-slip motion appropriate for the pull-apart model. Episode 3 post-dated the redbeds, leaving episode 2 as the best candidate for a basin-forming event.

Pull-apart basins (Burchfiel and Stewart 1966) are commonly developed along regional strike-slip fault systems. Studies of these natural pull-apart basins and experiments (e.g. Aydin and Nur 1982; Mann 1997; Mann et al. 1983; Peacock 1991; Peacock and Sanderson 1995; McClay and Dooley 1995) have proposed two models to explain the formation and evolution of large, transtensional basins along strike-slip faults: one model of transtensional and rhombohedral pull-apart basins at step-overs or releasing bends, and a second model of more elongate and rift-like basins produced by fault-normal extension coeval with strike-slip motion 
(Ben-Avraham and Zoback 1992). In addition, Mann (1997) proposed a third model for such basins involving tectonic escape.

The first pull-apart model is the most common one. The extensive New Brunswick Carboniferous redbed basin, into which the Waite fault zone continues northeastward as the Fredericton fault, was associated with the late Devonian-early Carboniferous rhomboidal Magdalen pull-apart basin in the Gulf of St. Lawrence (Bradley 1982). This pull-apart basin was generated at a releasing bend of a northeast-trending dextral strike-slip system, and the subsequent thermal subsidence affected a large area including most of New Brunswick during middle and late Carboniferous time (Bradley 1982). The Moncton basin in southern New Brunswick has also been viewed as a pull-apart basin associated with the same strike-slip system, and smaller pull-aparts created by similar strike-slip systems in the northern Appalachian orogen are possible (Bradley 1982).

The mechanisms for redbed basin development along the Norumbega fault system in eastern Maine have not been adequately addressed by previous workers. This study suggests that all the redbed basins in the Norumbega fault system in eastern Maine are pull-apart basins formed at releasing bends during a brittle phase of activity along the Waite fault zone (Fig. 1 and 2). Episode 1 master faults are not always straight but curve, bend, and anastomose locally, and episode 2 faulting mostly reactivated the episode 1 faults (e.g. Fig. 2), so that some releasing bends would have been expected to form. The pull-apart mechanism at the releasing bends fits the continuum model proposed by Mann et al. (1983). In this mechanism, pull-apart basins nucleate at releasing bend fault segments along the fault system, and initial opening across the bends produce spindle-shaped basins. Increased displacement on the strike-slip faults results in rhomboidal pull-aparts. The small redbed basins on Figure 1 appear to be examples of such rhomboidal pull-apart basins. With continued strike-slip displacement and a constant regional horizontal maximum principal stress orientation, the rhomboidal pull-apart basins would evolve into narrow elongate basins whose basin width might remain fixed by the width of the releasing bends or the initial fault separation if the shear strain is plane strain (Mann et al. 1983). The Norumbega (Fig. 1; Wones 1980; Fig. 2 of Bradley 1982), middle Nicatous Lake, and lower Nicatous Lake basins mapped in this study are examples of such long, narrow basins (Fig. 1 and 2). These basins were clearly synkinematic, and sedimentation may have accompanied their progressive opening.

Most of the redbed basins within the Norumbega fault system are small and narrow and characteristically contain pebble- and cobble-size sediments. These sediments are thick bedded (greater than $1 \mathrm{~m}$ ), generally poorly sorted, and range in shape from well rounded to angular and sub-angular. Only scarce outcrops of finer-grained redbeds such as red sandstone have been observed in the middle of Norumbega Basin and basins next to the Maine/ New Brunswick border on Fig. 1. This observation further supports the proposed dynamic synkinematic sedimentation environment. Because conglomerate predominates in almost all the redbed basins and the redbeds are uniformly steeply tilted, it is hard to reconstruct the distribution pattern of sedimentary facies and facies variations.

\section{CONCLUSIONS}

The shallow crustal segment of the Norumbega fault system in eastern Maine experienced ductile shearing during its initial dextral strike-slip activity at about $380 \mathrm{Ma}$. This faulting was related to late Acadian plate adjustments and was followed by three separate episodes of brittle faulting. The first two brittle episodes 1 and 2 predated deposition of post-Acadian redbeds distributed along the Waite composite fault zone and both involve dextral strikeslip motion although episode 1 had a significant dip-slip component. Episodes 1 and 2 probably occurred in the Late Devonian through Mississippian, well representing the deformation history in northern New England particularly in Maine during the transition from the Acadian to the Alleghanian orogenies. Episode 3 followed deposition of the redbeds and is attributed to the Alleghanian orogeny in the Permian. Paleostress analyses yielded different major compressive stress directions for the three post$380 \mathrm{Ma}$, brittle Norumbega faulting episodes in eastern Maine. $\sigma_{1}$ for the earliest (episode 1) and most intense event was oriented approximately WNW-ESE, but rotated to NE-SW for episode 2 and changed drastically to $\mathrm{N}-\mathrm{S}$ for episode 3 .

A Pennsylvanian age is suggested for the redbeds based on comparison with other post-Acadian rocks in Maine and adjacent New Brunswick, and because they appear to be secondcycle deposits that include large clasts of unmetamorphosed post-Acadian molasse that had been completely lithified prior to their inclusion in the redbeds. It is considered unlikely that the extensive Carboniferous deposits of eastern New Brunswick and Nova Scotia extended continuously into Maine. Rather, the redbeds most probably formed in small narrow basins created by transtensional processes within the brittle portions of the Waite composite fault zone.

\section{ACKNOWLEDGEMENTS}

This research was funded by the United States Geologic SurveyEDMAP and STATEMAP programs and by several PSC-CUNY faculty research grants. We are grateful to the Maine Geologic Survey, particularly State Geologist Robert Marvinney and Henry N. Berry IV, for their financial and logistical support and for stimulating discussions in the field and are deeply indebted to Brian Gayron for his superb field assistance. We wish to thank Bruce Idleman for constructive suggestions to improve the original manuscript, and Patrick Brock for help on thin-section analysis and other issues. Mark Swanson provided extremely valuable comments on an earlier version of this manuscript that led to significant improvements. We also appreciate the helpful reviews provided by Adrian Park, Heather Short, and Sandra Barr.

\section{REFERENCES}

Аввотт, R.N. 1978. Geology of the Red Beach granite. In New England Intercollegiate Geological Conference guidebook 
for field trips in southeastern Maine and southwestern New Brunswick. Edited by A. Ludman. pp. 17-37.

ANDERson, E.M. 1951. Dynamics of faulting and dyke formation, with applications to Britain: Edinburgh, Oliver and Boyd, 191 p.

ANGELIER, J. 1984. Tectonic analysis of fault slip data sets. Journal of Geophysical Research (B), 89, pp. 5835-5848.

ANGELIER, J. 1994. Fault slip analysis and paleostress reconstruction. In Continental Deformation. Edited by P.L. Hancock. Pergamon Press, Oxford. United Kingdom, pp. 53-100.

Aydin, A., \& Nur, A. 1982. Evolution of pull-apart basins and their scale independence. Tectonics, 1, pp. 91-105.

Ayuso, R.A., Arth, J.G., Sinha, A.K., Carlson, J., \& Wones, D.R. 1984. Comparative geochronology in the reversely zoned plutons of the Bottle Lake complex, Maine: $\mathrm{U}-\mathrm{Pb}$ on zircons and $\mathrm{Rb}-\mathrm{Sr}$ on whole rocks. Contributions to Mineralogy and Petrology, 88, pp. 113-125.

Ben-Avraham, Z., \& Zоваск, M.D. 1992. Transform-normal extension and asymmetric basins: An alternative to pull-apart models. Geology, 20, pp. 385-480.

Bradley, D.C. 1982. Subsidence in late Paleozoic basins in the Northern Appalachians. Tectonics, 1, pp.107-123.

BRAdLey, D.C. 1988. Carboniferous strike-slip and foreland tectonics of the Canadian Appalachians, and implications for the evolution of coastal New England. Geological Society of America Abstracts with Programs, 29, pp. 9.

Bradley, D.C., Tucker, R.D., \& McGregor, D.C. 1998. Late Silurian to middle Devonian migration of the Acadian deformation front across Maine. Geological Society of America Abstracts with Programs, 30, pp. 7.

Burchfiel, B.C., \& Stewart, J.H. 1966. A Pull-apart origin of the central segment of Death Valley, California. Geological Society of America Bulletin, 77, pp. 439-442.

Craddock, J.P., Jackson, M., Van Der Pluijm, B.A., \& VersiCAL, R.T. 1993. Regional shortening fabrics in eastern North America: Far-field stress transmission from the AppalachianOuachita orogenic belt. Tectonics, 12, pp. 257-264.

Davis, G.H., \& REYNOLDS, S.J. 1996. Structural Geology of Rocks and Regions. John Wiley \& Sons, Inc. New York. 776p.

Dean, S.L., Kulander, B.R., \& Skinner, J.M. 1988. Structural chronology of the Alleghanian orogeny in southeastern West Virginia. Geological Society of America Bulletin, 100, pp. 299-310.

Doll, W.E., Domoracki, W.J., Costain, J.K., Coruh, C., Ludman, A., \& Hopeck, J.T. 1996. Implications of a seismic reflection profile across part of the Norumbega fault zone, eastcentral Maine. Geology, 24, pp. 251-254.

ENGELDER, T., \& GEISER, P. 1980. On the use of regional joint sets as trajectories of paleostress fields during the development of the Appalachian Plateau. Journal of Geophysical Research (B), 85, pp. 6319-6341.

Evans, M.A. 1994. Joints and decollement zones in Middle Devonian shales: Evidence for multiple deformation events in the central Appalachian Plateau. Geological Society of America Bulletin, 106, pp. 447-460.

Faure, S., Tremblay, A., \& Angelier, J. 1996, Alleghanian paleostress reconstruction in the northern Appalachians: Intraplate deformation between Laurentia and Gondwana. Geological Society of America Bulletin, 108, p. 1467-1480.

Gates, A.E., Speer, J.A., \& Pratt, T.L. 1988. The Alleghanian southern Appalachian Piedmont: a transpressional model. Tectonics, 7, pp. 1307-1324.

HiLl, M.D., \& Аввот, R.N. 1989. Commingled gabbroic and granitic magmas in the northern Bays-of Maine igneous complex, Calais area. In Studies in Maine Geology, volume 4: Igneous and Metamorphic Geology. Edited by R.D. Tucker and R.G. Marvinney. Augusta, Maine Geological Survey, pp.35-44.

HogAn, J.P., \& SinHA, A.K. 1989. Compositional variation of plutonism in the coastal Maine magmatic province: model of origin and tectonic setting. In Studies in Maine Geology, volume 4: Igneous and Metamorphic Geology. Edited by R.D. Tucker and R.G. Marvinney. Augusta, Maine Geological Survey. pp. 1-34.

Hubbard, M.S., West, D.P., Jr., Ludman, A., Guidotti, C.V., \& Lux, D.R. 1995. The Norumbega fault zone, Maine: Mid shallow level crustal section within a transcurrent zone. Atlantic Geology, 31, pp.109-116

IDLEMAN, B., \& LudMAN, A. 1998. Cooling history of the Deblois pluton: Implications for Mid- to Late-Paleozoic deformation in eastern Maine. Geological Society of America Abstracts with Programs, 30, pp. 27.

JURINSKI, J.B. 1987. The Baring pluton: contaminated granite of the Moosehorn Igneous Complex: Honors Thesis, Virginia Polytechnic Institute and State University, Blacksburg, Virginia, $48 \mathrm{p}$.

LARRABEe, D.M. 1964. Reconnaissance bedrock geology of the Wabassus Lake quadrangle, Washington County, Maine. United States Geological Survey, Mineral Investigation Field Studies Map MF-282, 1:62,500.

Ludman, A. 1991. The Fredericton Trough and Norumbega fault zone in eastern Maine. In Geology of the Coastal Lithotectonic Block and Neighboring Terranes, Eastern Maine and Southern New Brunswick. Edited by A. Ludman. New England Intercollegiate Geological Conference Guidebook. pp. 186-206.

Ludman, A. 1998. Evolution of a transcurrent fault system in shallow metasedimentary rocks: the Norumbega fault zone, eastern Maine. Journal of Structural Geology. 20, pp.93-107

Ludman, A., \& Gibbons, S. 1999. Multistage shearing of the Deblois granite in the Kellyland fault zone, eastern Maine. In Norumbega Fault System of the Northern Appalachians. Edited by A. Ludman and D. West. Geological Society of America, Special Paper 331. pp. 41-58.

Ludman, A., Lanzirotti, A., Lux, D., \& Wang, C. 1999. Constrains on timing and displacement of multiple shearing in the Norumbega fault system, eastern Maine. In Norumbega Fault System of the Northern Appalachians. Edited by A. Ludman and D. West. Geological Society of America, Special Paper 331. pp. 179-194.

Ludman, A., Wang, C., Gibbons, S., Idleman, B., \& Rasbury, T. 2000. Geometry and timing of multiple faulting events in the Kellyland fault zone (Norumbega fault system) in the Fletcher Peak-Wabassus Mountain area, eastern Maine. In 
Guidebook for field trips in coastal and east-central Maine. Edited by M. Yates, D. Lux, and J. Kelley. New England Intercollegiate Geologic Conference Guidebook. 92, pp. 1-22.

ManN, P. 1997. Model for the formation of large, transtensional basins in zones of tectonic escape. Geology, 25, pp. 211-214.

Mann, P., Hempton, M.R., Bradley, D.C., \& Burke, K. 1983. Development of pull-apart basins. Journal of Geology, 91. pp. 529-554.

McClay, K., \& Dooley, T. 1995. Analogue models of pull-apart basins. Geology, 23, pp. 711-714.

McLeod, M.J., Johnson, S.C., \& Ruitenberg, A.A. 1994. Geological map of southwestern New Brunswick. New Brunswick Department of Natural Resources and Energy Map NR-5, scale 1:250,000.

Osberg, P.H., Hussey, A.M.I., \& Boone, G.M. 1985. Bedrock geologic map of Maine: Maine Geologic Survey, Augusta, Maine, scale 1:500,000.

РеAсоск, D.C.P. 1991. Displacement and segment linkage in strike-slip fault zones. Journal of Structural Geology, 13, pp. 1025-1035.

Peacock, D.C.P., \& Sanderson, D.J. 1995. Pull-aparts, shear fractures and pressure solution. Tectonophysics, 241, pp. $1-13$.

Ramsay, J.G., \& Huber, M. 1983. The Techniques of Modern Structural Geology, Vol.1: Strain Analysis. Academic Press, New York. 307p.

Short, H. 2000. Acadian transpression and the exhumation of the sillimanite-bearing Passagassawakeag terrane along the Liberty-Orrington Fault, coast Maine. Atlantic Geology, 36, pp. 27-39.

Sierra, F., Schedl, A., McCabe, C., \& Robbins, D.R. 1993. Deformation and magnetization of the Hudson River Valley, eastern New York: Results of a study of calcite twinning and anisotropy of magnetic remanence in the Onondaga Limestone. Tectonophysics, 217, pp. 321-329.

Stewart, D.B., \& Wones, D.R. 1974. Bedrock geology of the northern Penobscot Bay area. In Geology of east-central and north-central Maine. Edited by P. Osberg. New England Intercollegiate Geological Conference Guidebook, 66, pp. 223-239.

Swanson, M.T. 1992. Late Acadian-Alleghanian transpressional deformation: evidence from asymmetric boudinaged in the Casco Bay area, coastal Maine. Journal of Structural Geology, 14, pp.323-341.

Swanson, M.T. 1995. Distributed ductile dextral shear strain throughout the Casco Bay area. In Guidebook to field trips in southern Maine and adjacent New Hampshire. Edited by A. Hussey II, and R.A. Johnson. New England Intercollegiate Geologic Conference Guidebook, 87, pp. 1-13.

Swanson, M.T. 1999. Dextral transpression at the Casco Bay restraining bend, Norumbega fault zone, coastal Maine. In Norumbega Fault System of the Northern Appalachians. Edited by A. Ludman and D. West. Geological Society of America, Special Paper 331. pp. 85-104.

Wang C., \& Ludman, A. 1999. Deformation history of the Norumbega fault system in the Fletcher Peak 7.5' quadrangle, eastern Maine. Geological Society of America Abstracts with programs, 31, A77.

Wang C., Ludman, A., \& Gayron, B. 2000. Ductile shear geometry of the Norumbega fault system in the Great Pond-Grand Lake Stream area, eastern Maine. Geologic Society of America Abstracts with Programs, 32, no.1, A81.

West, D.P., Jr., Ludman, A., \& Lux, D.R. 1992. Silurian age for the Pocomoonshine gabbro-diorite and its regional tectonic implications. American Journal of Science, 191, pp. 252-273.

West, D.P., JR., \& Lux, D.R. 1993. Dating mylonitic deformation by the 40Ar-39Ar method: an example from the Norumbega fault zone, Maine. Earth and Planetary Science Letters, 120, pp.221-237.

West, D.P., JR., \& Hubbard, M.S. 1997. Progressive localization of deformation during exhumation of a major strike-slip shear zone: Norumbega fault zone, south-central Maine, USA. Tectonophysics, 273, p. 185-202.

West, D.P., JR. 1999. Timing of displacements along the Norumbega fault system, south-central and south-coastal Maine. In Norumbega Fault System of the Northern Appalachians. Edited by A. Ludman and D. West. Geological Society of America, Special Paper 331. pp. 167-178.

WonEs, D.R. 1978. Norumbega fault zone, Maine; US Geologic Survey Summary of Technical Reports VIII, National Earthquake Hazards Reduction Program, pp.108-111.

WonEs, D.R. 1980. Contributions of crystallography, mineralogy, and petrology to the geology of the Lucerne pluton, Hancock County, Maine. American Mineralogist, 65, pp. 411-437.

Wones, D.R., \& Ayuso, R.A. 1993. Geological map of the Lucerne granite, Hancock and Penobscot counties, Maine. United States Geological Survey, Miscellaneous Investigation Series Map I-2360, scale 1: 125,000.

Editorial responsibility: Sandra M. Barr 